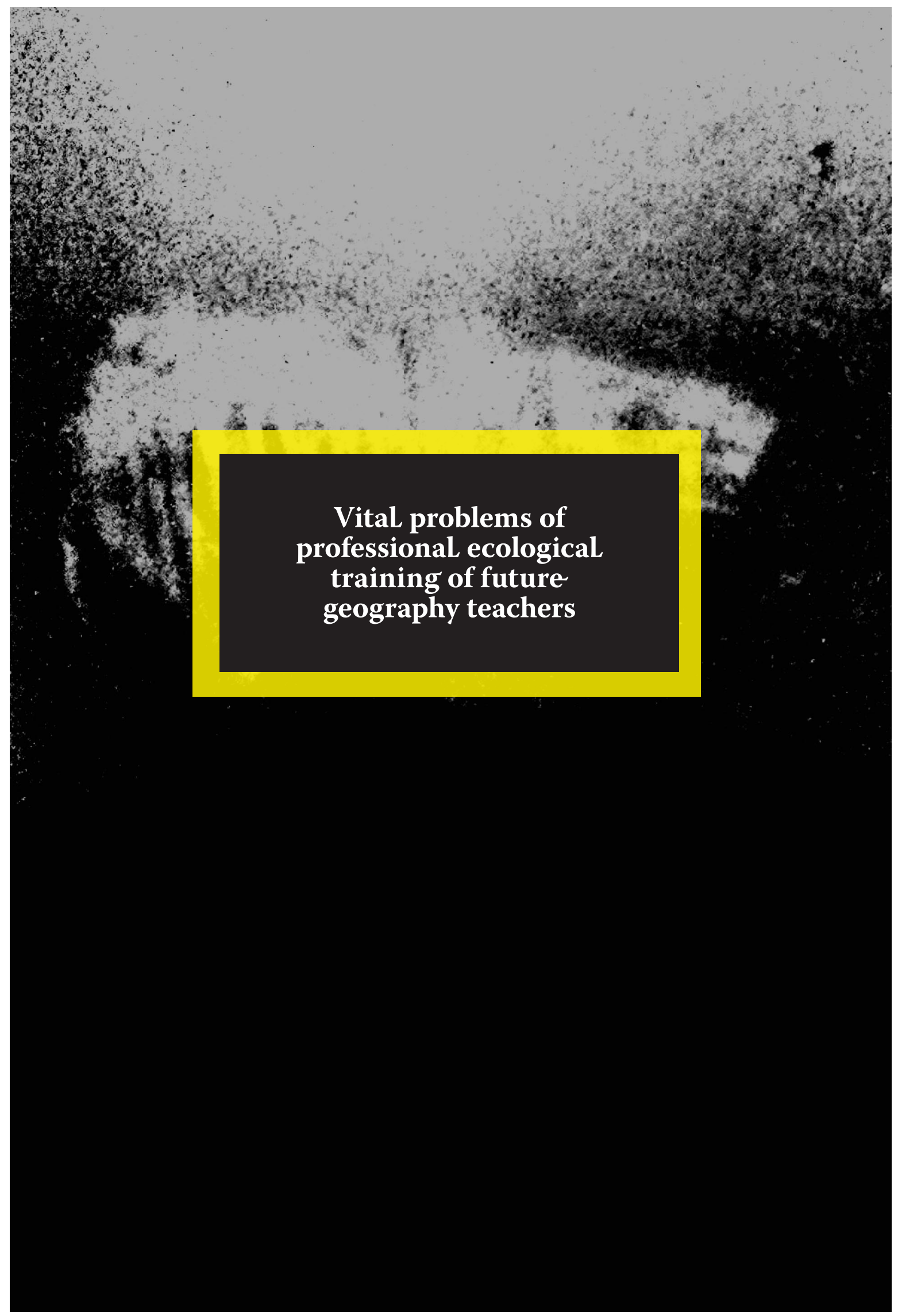




\title{
VITAL PROBLEMS OF PROFESSIONAL ECOLOGICAL TRAINING OF FUTURE GEOGRAPHY TEACHERS
}

\section{PROBLEMAS VITALES DE LA FORMACIÓN ECOLÓGICA PROFESIONAL DE FUTUROS PROFESORES DE GEOGRAFÍA}

\author{
Authors \\ Renat Ilgizarovich Gaisin, Kazan Federal University. Russia. \\ Ruslan Anatolivich Ulengov, Kazan Federal University. Russia. \\ Ildar Anvarovich Urazmetov, Kazan Federal University. Russia. \\ Elena Nikolaevna Kubyshkina, Kazan Federal University. Russia. \\ E-mail:ulengovr@mail.ru
}

Fecha de recibido: 13 de noviembre de 2019

Fecha de aceptado para publicación: 30 de noviembre de 2019

Fecha de publicación: 10 de diciembre de 2019

\begin{abstract}
The article analyzes the problems of professional ecological training of future geography teachers and the approaches to the educational process ensuring the foundation and development of professional ecological competences. The main aspect of the system of ecological education and up-bringing is the system of ecological activities. Introduction of new original technologies and methods into constant teaching practice affects to significant extent the level of contemporary school education. It is evident that modern ecology has transformed from one of branches of biology into s significant range of knowledge including in practice almost all branches of science. Within the frames of school education as well as biology geography is the major subject in forming ecological competence of a student. The main purpose of ecological education is shaping ecological competence of students with further ecological competency. The aim of the article is to demonstrate the analyses of the model of professional ecological competency of would-be teachers of geography.
\end{abstract}

Keywords: social-and-economic problems, professional ecological competences, competence model of professional ecological training of students.

El artículo analiza los problemas de la formación ecológica profesional de los futuros profesores de geografía y los enfoques del proceso educativo que garantizan la base y el desarrollo de las competencias ecológicas profesionales. El aspecto principal del sistema de educación ecológica y educación es el sistema de actividades ecológicas. La introducción de nuevas tecnologías y métodos originales en la práctica docente constante afecta en gran medida el nivel de la educación escolar contemporánea. Es evidente que la ecología moderna se ha transformado de una de las ramas de la biología en una amplia gama de conocimientos, incluida en la práctica casi todas las ramas de la ciencia. Dentro de los marcos de la educación escolar, así como la biología, la geografía es el tema principal en la formación de la competencia ecológica de un estudiante. El objetivo principal de la educación ecológica es dar forma a la competencia ecológica de los estudiantes con mayor competencia ecológica. El objetivo del artículo es demostrar los análisis del modelo de competencia ecológica profesional de los futuros profesores de geografía.

Palabras clave: problemas sociales y económicos, competencias ecológicas profesionales, modelo de competencia de formación ecológica profesional de los estudiantes. 


\section{Introduction.}

The significance of the development of environmental education in higher education system is determined by the dynamic processes of greening science, culture, economics and politics. The analysis of the research on the development of innovations in the system of environmental education shows that their content and structure are predetermined by a number of problems which are exacerbated by a number of contradictions:

- the existing system of the development of environmental education and the need for the formation of new value orientations in man and nature relationship;

- the presence of integration processes in environmental education and the lack of necessary software;

- the presence of innovative processes in the practice of environmental education and the lack of equal expertise of the school teacher for ecological training;

- a critical social need for the education of a value-semantic attitude to nature and for the consumer essence of modern industrial civilization, etc.

Modern problems of the society-nature interaction (socio-environmental problems) determine the content of the training of a would-be teacher. The essence and characteristics of the pedagogical sphere translate into the pedagogical component of the process of training which requires the goals of professional education to be determined and formulated with allowance for socio-environmental component, corresponding to the substantive and procedural aspects of higher learning. The leading role in building younger generation's environmental awareness is played by the teacher. It is the teachers who, during the lessons and after school hours, are destined to form a system of scientific knowledge, views and valuable ideas that the danger of an impending environmental catastrophe can be prevented only by immediate and radically improved activities aimed at nature conservation. Environmental compliance means to possess a whole range of environmental skills which a person can acquire in the process of special training. A certain amount of environmental skills must be mastered from an early age, which suggests that the teacher should be well prepared for this mission. This concerns the teacher of natural science (teachers of chemistry, biology, geography) especially near. Moreover, a teacher who possesses these skills and is able to transfer them to students can solve a similar problem.

The system of attainment targets for the students of future teaching profession should be represented by the goals related to the actual socio-environmental problems, the need to solve them in the present and future. The social mechanism for the effective solution of environmental problems depends not only on the effectiveness of state policy in this area, but also on the level of development of environmental science, on the maturity of public consciousness, including the assessment of the relevance of ecology for human life reflected in the media and, finally, on the professionalism of those people who assume leading the others through specific environmental actions.

The stated goals, in turn, determine the content of education in this area, are reflected in a combination of methods, means and forms of its acquisition, diagnostic features, which also constitutes a separate problem. 


\section{Methods.}

Undoubtedly, the decisive force for large-scale environmental education is the proficiency of secondary school teachers as environmental culture bearers who transmit this culture to their young charges. Accordingly, the teacher's ability to fulfill the mentioned mission is formed and programmed in the system of his training in the conditions of pedagogical college. Comparing the accumulated layer of research in different directions of solving the whole complex of problems of environmental education, we have to admit their insufficiency at the level of further improvement of environmental and professional training of future teachers.

From the standpoint of the activity approach, environmental education of students involves a special type of educational activity, prompted by the need to solve socioenvironmental problems, which is the most important condition for the further sustainable development of society, aimed at training specialists who are able, within the framework of their chosen profession, to establish harmonious relations with the environment based on historically and spatially related measures, norms and rules of environmental management. A teacher, in particular, a chemistry teacher, a geography teacher, a biology teacher who not only realize the essence of environmental problems but are also destined to instill in their young charges a sense of responsibility for the conservation of Nature's living world, striving to multiply generations of people who will follow appropriate principles throughout life. Ecological training of students, as an integral pedagogical process, is the learning and education of students, the purpose of which is to acquire new scientific knowledge about the environment, modern types and methods of rational nature management; new standards for interaction with the environment; students' mastering new socio-ecological technologies that save the living environment for present and future generations; mastering the experience of creative (constructive) activities in the environment, the experience of human relations with the environment: the relationship of love, selflessness, self-sacrifice in cooperation with it. The process of environment attitude development can be successful if it is carried out continuously. Environmental education implies a harmonious relationship of the intellectual, emotional-aesthetic and practically effective attitude of a person to nature, which ensures the formation of an ecological culture, an active personality to improve and preserve the environment. Most authors admit that the content of environmental training is a combination of interdisciplinary-ecological ideas, scientific, and moral-ecological concepts, intellectual and practical skills, and experience in creative (environmental) activities to be mastered [10].

\section{Results and Discussion.}

The modern pedagogical science developing the issues of environmental education and environmental awareness training proceeds from the fact that the formation of an attitude towards nature is an integral element in shaping the worldview of the younger generation. The problem of environmental education is, first of all, the problem of the formation of a scientific worldview, since it is the core of consciousness, it gives the unity to the spiritual self of a person, equips him with socially significant and environmentally acceptable principles of approach to the natural environment.

Famous American biologist B. Kommoner built a system of environmental laws: 
everything is related to everything else: the universal connection of processes and phenomena in nature;

everything must disappear: no matter how tall the plant's pipe, it cannot throw waste outside the biosphere;

nature knows better: human actions must be coordinated with natural processes;

one gets nothing for nothing: any action in nature does not pass away without leaving a trace, and the protection of nature and the rational use of natural resources are unthinkable without certain economic costs, "he also opposed the theory of "freezing progress" [1].

Environmental education is a purposefully organized, methodical and systematic process of mastering environmental knowledge, skills and abilities [2].

According to V.E. Meshechko, "environmental education should be continuous, encompass family, pre-school, school and after school education and training" [3].

In a modern perspective, of interest is the point of view of S. V. Alekseev [4,5], who claims that environmental education for sustainable development is a new integrated direction within the framework of the system of continuous environmental education which is being formed in many countries of the world with the purpose of ensuring the movement of society towards balanced development.

The process of integrating the natural sciences, this integrity, currently contributes to the implementation of the ideas of scientists: about the mutual penetration of sciences, the humanization of science, deepening the integrating relations between different fields of scientific knowledge $[6,7,8]$.

Summarizing the aforesaid, it should be noted that environmental concepts in the modern scientific worldview allow revealing the current trends in the direction of the development of environmental education in the above theories and practices.

The theoretical and pedagogical basis of environmental education is a modern scientific worldview in which real environmental problems are significant, and their solution is a prerogative of the joint activities of teachers and students.

The theoretical model of professional environmental education of students helps to identify unresolved issues of environmental education of students (continuity, interdisciplinarity, etc.) and determines the constructive tasks, the direction of their research and decision $[9,10]$.

\section{Summary.}

The competency-based model of professional environmental training of students, determined by the level of professional education per se, experience, individual personality characteristics, its desire for self-education, self-improvement, creativity, a responsible attitude to business. The development of the structure of a teacher's ecological competence has scientific, theoretical and practical significance. This problem lies at the crossroads of structuring personal culture, pedagogical culture and the culture of relations with nature. The student's ecological competence includes the following components: a) cognitive; b) 
motivational value; c) activity-practical. The cognitive component assumes the formation of a system of environmental knowledge (natural science, worldview, regulatory, practical) that serves as the basis for choosing a method for environmental activities. The motivational-value component should be understood as the existing system of motivationalvalue formations: interests, needs, beliefs, value ideas that encourage environmental activities; socially significant motives.

The activity-practical component in the structure of environmental competence of students ensures the formation of environmental skills, compliance with norms and rules of behavior in nature, taking into account environmental requirements, practical experience in environmental activities. The level of development of environmental competence of students depends on the formation of appropriate skills. Skills as an alloy of skills and knowledge that determines the quality of any activity, a much more complex education than a single skill or knowledge.

The structure of the competency model should be determined by the following professional and environmental competencies (Table 1).

Table 1.Structural and Functional Characteristics of Professional and Environmental Competencies

\begin{tabular}{|l|l|}
\hline Competences & $\begin{array}{l}\text { The content, definition and structure of the competence. The description of baseline of } \\
\text { competence }\end{array}$ \\
\hline $\begin{array}{l}\text { The ability to study and estimate the state } \\
\text { of the natural environment }\end{array}$ & $\begin{array}{l}\text { The competence lies in the ability to reveal the main categories of impact on the } \\
\text { environment, the categories of environment change; to identify, assess and forecast the } \\
\text { consequences of anthropogenic change of environment; to elaborate a comprehensive set of } \\
\text { measures of smart use of natural resources; to perform diagnosis of the state of natural } \\
\text { objects }\end{array}$ \\
\hline $\begin{array}{l}\text { The ability to espouse environmental } \\
\text { ideas about shared responsibilities for } \\
\text { preservation of vital environment and } \\
\text { inorganic nature }\end{array}$ & $\begin{array}{l}\text { The competence lies in the ability to cause the performance of mass environmental } \\
\text { campaigns and actions, the student's treatment of nature as values; to use the information } \\
\text { about environmental situation in Russia and the major public environmental protection } \\
\text { policy }\end{array}$ \\
\hline $\begin{array}{l}\text { Readiness to engage in particular actions } \\
\text { concerning nature conservation and } \\
\text { environmental remediation }\end{array}$ & $\begin{array}{l}\text { The competence lies in the ability to analyze the productivity of communication in the } \\
\text { process of ecological activity; the ability to arrange various environmental friendliness } \\
\text { oriented forms of activity outdoors }\end{array}$ \\
\hline $\begin{array}{l}\text { The ability to analyze and generalize } \\
\text { progressive educational experience in } \\
\text { education of ecological culture; }\end{array}$ & $\begin{array}{l}\text { The competence lies in the ability to analyze and generalize the knowledge acquired from } \\
\text { studying pedagogical and methodical materials, to analyze education situations related to } \\
\text { solving ecological and educational problems; the desire to increase the level of the students' } \\
\text { environmental consciousness }\end{array}$ \\
\hline
\end{tabular}

\section{Conclusions}

The Kazan Federal University provides a process of forming professional environmental competencies of future geography teachers. The competencies are formed in three stages.

1 theoretical stage the purpose of which is the familiarization with the situations of applying, studying the technologies of interaction of man with nature in the process of learning subjects of the theoretical and professional cycle. The subjects of theoretical learning are the following groups of disciplines: humanitarian and socio-economic, mathematical and natural-scientific, general professional, subject-specific training disciplines and additional specialization disciplines. 
2 technological stage the purpose of which is the mastering of skills in the process of practical learning. The implementation of the second stage takes place within the framework of field practices, such as meteorology, topography, geology, etc.

3 qualification stage the purpose of which is the transfer of environmental skills to students. This stage includes research activities, teaching practice, extracurricular environmental activities.

Based on the presented scheme, a technology for the formation of professional environmental competencies of future geography teachers in the educational process of a pedagogical college has been developed and is being successfully implemented.

Based on the presented scheme, a technology for the formation of professional environmental competencies of future geography teachers in the educational process of the pedagogical direction has been developed and is being successfully implemented. An effective approach to implementing environmental education in practice requires the ecologization of educational processes on the basis of a systematic approach: through the pre-education of the content component, through the use of the necessary technologies for the formation of students with a sufficient level of environmental competence. A decisive factor for the implementation of large-scale environmental education is the competence of teachers of comprehensive school - the bearers of environmental culture, who transmit this culture to their young charges. Therefore, one of the most important problems is the problem of the development of professional environmental competencies of future teachers as an important component of their overall ecological and moral culture and the conditions for the availability of high pedagogical qualifications.

\section{Acknowledgements}

The work is performed according to the Russian Government Program of Competitive Growth of Kazan Federal University.

\section{References}

Khoroshavina S. G. The Concepts of Modern Natural Science. The Course of Lectures. Rostov on the Don: Phenix Press, 2002. - 480 p.

Korobkin V. I., Peredelsky L. V. Ecology. - Rostov on the Don: Phenix Press, 2001. - 576 p.

Meshechko E.N. The Basics of Ecology: The Textbook Edited by E.N. Meshechko. - Mn.: Ecoperspective, 2002. - $376 \mathrm{p}$.

Alekseyev S.V. From Ecological Education Towards Education for sustainable Development: Search for a Strategy, Approaches, Technologies. - SBb, 2001. - P.7-9.

Samigullina, G.S., Moiseeva, L.V., Gaisin, I.T., Vlasova, E.I.Meta-methodological implementation of creativity in ecogeographical education disciplines Life Science Journal 11(9 SPEC. ISSUE),73, p. 341-345

Vlasova, E.I., Gaisin, I.T., Gaisin, R.I., Khusainov, Z.A., Kamahina, R.S. Criteria for the educational process in the assimilation of students' knowledge International Business Management Volume 10, Issue 23, 2016, Pages 5616-5619 
Gaisin I. T., Gaisin R.I., Sarachoglu Z. Continuity of Ecological and economic Education of the Learners of General and Professional Educational Establishments //Samara Science Journal. 2015. № 1. P. 55.

Ulengov R. A., Gabdrakhmanov N. K. The Problems and Prospects of Application of Information Technologies in Ecological Education of the Youth // Burning Issues of Human Ecology: Social Aspects. The Collection of Research Papers of the Participants of International Science and Practice Conference: In 3 Volumes. 2017. P. 159-163.

Smirnova E.V., Urazmetov I.A., Valeeva A.A. interdisciplinary role of the course of soil study in realization of environment education in higher education. International Multidisciplinary Scientific GeoConference SGEM. 2017. T. 17. № 54. P. 81-88.

Kubyshkina E.N., Urazmerov I. A. The Urgency of Ecological Education in Training Future Geography Teachers at Present Stage. Kazan Science. 2016. № 4. P. 125-127. 